\title{
Derajat Keparahan Pneumonia Komunitas pada Geriatri Berdasarkan Skor CURB-65 di Bangsal Penyakit Dalam RS. Dr. M. Djamil Padang Tahun 2016
}

\author{
Mecy Alvinda Sari ${ }^{1}$, Raveinal $^{2}$, Noverial $^{3}$
}

\begin{abstract}
Abstrak
Skor CURB 65 merupakan salah satu sistem prediksi derajat keparahan pneumonia komunitas yang cukup mudah dan valid namun tingkat prediksinya tidak cukup tinggi dalam menentukan risiko mortalitas. Tujuan penelitian ini adalah untuk mengetahui derajat keparahan pneumonia komunitas pada geriatri berdasarkan skor CURB-65 di Bangsal Penyakit Dalam RS. Dr. M. Djamil Padang tahun 2016. Jenis penelitian ini adalah deskriptif retrospektif. Penelitian dilakukan dari November 2016 sampai April 2017 di Bangsal Penyakit Dalam Rumah Sakit Dr. M. Djamil Padang dan bagian Rekam Medik Rumah Sakit Dr. M. Djamil Padang. Pengambilan sampel menggunakan teknik total sampling dan data diolah secara manual dalam bentuk tabel. Dari 365 sampel yang didata, 167 (45,75\%) sampel berasal dari laki-laki, dan 198 (54,25\%) sampel dari perempuan. Kelompok usia dengan frekuensi tertinggi adalah 6069 tahun 159 (43,56\%). Skor CURB-65 terbanyak pada pasien Pneumonia Komunitas adalah skor 2 yaitu 132 $(36,16 \%)$ pasien. Derajat keparahan pneumonia komunitas tertinggi didapatkan pada derajat berat sebanyak 167 $(45,75 \%)$ pasien. Hasil didapatkan 156 (42,74\%) pasien meninggal dengan perbandingan perempuan lebih besar dibandingkan laki-laki yaitu $22,47 \%$ dan $20,27 \%$. Simpulan penelitian ini adalah derajat keparahan pneumonia komunitas pada geriatri berdasarkan skor CURB-65 yang dirawat di Bangsal Penyakit Dalam Rumah Sakit Dr. M. Djamil Padang tahun 2016 yang terbanyak adalah derajat berat.
\end{abstract}

Kata Kunci: pneumonia komunitas, CURB-65, derajat keparahan pneumonia komunitas

\section{Abstract}

CURB-65 score is a system that can predict the severity degree of Community Acquired Pneumonia (CAP) in an easy and valid way, but the prediction level is not high enough on deciding the mortality score. The objective of this study was to know the severity degree of CAP on geriatry by using CURB-65 score in Internal Medicine Department of Dr. M. Djamil Hospital in Padang on 2016. This research was a descriptive retrospective. This research was done in November 2016 to April 2017 at Internal Medicine Department on Dr. M. Djamil Hospital Padang and at Medical Record Department of Dr. M. Djamil Hospital Padang. The sampling method that was used is total sampling and the data was processed manually in form of tables. From 365 samples that were splected, 167 (45,75\%) samples were males, and 198 (54,25\%) samples were females. The age group with the highes fequency is 60-69 years old which are 159 (43,56\%). The most frequent CURB-65 score on CAP patients is score 2 which are 132 (36,16\%) patients. In the other hand, the most frequent severity degree on CAP which are 167 (45,75\%) patients. It was obtained that 156 $(42,74 \%)$ patients died with the comparison female is more frequent than male which are $22,47 \%$ and $20,27 \%$. The conclusion is the most frequent severity degree of CAP on geriatry by using CURB-65 score in Internal Medicine Department of Dr. M. Djamil Hospital in Padang on 2016 is severe.

Keywords: community acquired pneumonia, CURB-65 score, severity degree of CAP 
Affiliasi penulis: 1. Prodi Pendidikan Dokter Fakultas Kedokteran Universitas Andalas Padang (FK Unand; 2. Bagian IImu Penyakit Dalam FK Unand; 3. Bagian Bedah Unand

Korespondensi: Mecy Alvinda Sari. Email: mecy.alvinda@gmail.com Telp: 085263751172

\section{PENDAHULUAN}

Pneumonia merupakan penyakit infeksi saluran napas bawah akut pada parenkim paru. Pneumonia disebabkan oleh mikroorganisme seperti bakteri, virus, jamur dan parasit. Peradangan pada paru yang disebabkan oleh Mycobacterium tuberculosis tidak dikategorikan ke dalam pneumonia. ${ }^{1}$

Kejadian pneumonia cukup tinggi di dunia, yaitu sekitar 15\%-20\%. Dan pneumonia menjadi penyebab kematian kelima pada geriatri. ${ }^{2}$ Pneumonia pada geriatri sulit terdiagnosis karena sering asimptomatik. Gejala yang sering timbul pada geriatri yaitu badan terasa tidak enak. Penurunan aktivitas fisik, penyakit penyerta, proses penuaan, dan status gizi kurang memberikan dampak terhadap pneumonia berat pada geriatri. $^{3}$ Pneumonia komunitas merupakan jenis pneumonia bakterial yang didapat dari masyarakat. ${ }^{1}$

Pneumonia komunitas atau Community Acquired Pneumonia (CAP) merupakan proses inflamasi yang terjadi di parenkim paru yang menjadi penyebab kematian tertinggi pada geriatri. ${ }^{4}$ Jumlah geriatri yang semakin banyak akan meningkatkan penyakit kronik, keterbatasan fisik, morbiditas, mortalitas dan biaya perawatan penyakit akut. ${ }^{3}$ Salah satu kelompok berisiko tinggi untuk pneumonia komunitas adalah geriatri dengan usia 65 tahun atau lebih. $^{5}$

Di Indonesia, prevalensi kejadian pneumonia pada tahun 2013 sebesar 4,5\%. ${ }^{6}$ Pneumonia merupakan salah satu dari 10 besar penyakit rawat inap di rumah sakit, dengan proporsi kasus 53,95\% laki-laki dan 46,05\% perempuan. Pneumonia memiliki tingkat Case Fatality Rate (CFR) yang tinggi, yaitu 7,6\%. ${ }^{1}$ Berdasarkan data Riset Kesehatan Dasar (Riskesdas) 2013, prevalensi pneumonia pada geriatri mencapai $15,5 \%{ }^{6}$

Pada tahun 2013, pneumonia ditemukan dengan prevalensi $3,1 \%$ di Sumatera Barat. ${ }^{6}$ Di Kota
Padang jumlah kunjungan pengobatan pneumonia mengalami kenaikan dari tahun 2008 hingga 2013, dengan 5878 kasus pada 2008 dan 8970 kasus pada 2013. ${ }^{8}$

Berdasarkan penelitian Rose Dinda Martini pada tahun 2013 mengenai prealbumin dan CURB-65 sebagai faktor prediktor kematian pada pasien usia lanjut dengan pneumonia komunitas didapatkan jumlah pasien pneumonia 158 pasien, terdiri dari 82 orang laki-laki dan 76 orang perempuan. Subjek tersebut terdiri dari 155 pasien yang dirawat di bagian Penyakit Dalam RS Dr. M. Djamil dan 3 pasien yang dirawat di RS Dr. Yos Sudarso Padang. Didapatkan pasien terbanyak pada kelompok usia 60-69 tahun (43,0\%). Pada penilaian dengan skor CURB-65 terbanyak adalah skor $3(34,8 \%)$ dan skor 2 (33,5\%). Didapatkan mortalitas dari 158 orang dengan perawatan 30 hari sebesar 50 orang. ${ }^{9}$

Berdasarkan Infectious Diseases Society of America (IDSA), American Thoracic Society (ATS), dan British Thoracic Society (BTS) ada beberapa skor yang dapat digunakan untuk memprediksi derajat keparahan dari pneumonia, antara lain Pneumonia Severity Index (PSI) dan CURB-65 (Confusion, Urea, Respiratory rate, Blood pressure, Umur $\geq 65$ tahun). Skor prediksi derajat keparahan pneumonia ini penting dalam penatalaksanaan pasien agar angka kematian pada pasien CAP dapat berkurang. ${ }^{10}$

CURB-65 dilihat berdasarkan lima gambaran klinik utama yaitu confusion (kesadaran), urea (nilai ureum dibagi 2,14), respiratory rate (frekuensi napas), blood pressure (tekanan darah), dan usia $\geq 65$ tahun yang sangat praktis, mudah diingat dan dinilai. ${ }^{11}$ Kelebihan skor CURB-65 adalah penggunaannya yang mudah dan dirancang untuk lebih menilai keparahan penyakit dibandingkan dengan PSI yang menilai risiko mortalitas. ${ }^{12}$ Skor CURB-65 lebih baik dalam menilai pasien pneumonia berat dengan risiko mortalitas tinggi. ${ }^{13}$

Berdasarkan latar belakang di atas, perlu untuk diteliti tentang gambaran derajat keparahan pneumonia komunitas pada geriatri dilihat dari skor CURB-65. 


\section{METODE}

Penelitian deskriptif retrospektif ini dilakukan di Bangsal Penyakit Dalam Rumah Sakit Dr. M. Djamil Padang dan bagian Rekam Medik Rumah Sakit Dr. M. Djamil Padang pada bulan November 2016 sampal April 2017.

Studi dilakukan pada pasien geriatri yang dirawat dengan diagnosis pneumonia komunitas di Bangsal Penyakit Dalam Rumah Sakit Dr. M. Djamil Padang (HCU, Interne Pria, dan Interne Wanita) periode 1 Januari 2016 - 31 Desember 2016 yang memenuhi kriteria inklusi dan eksklusi saat di rawat. Kriteria inklusi adalah usia $\geq 60$ tahun, didiagnosis pneumonia komunitas, terdapat lima gambaran klinik utama skor CURB-65. Kriteria eksklusi adalah Pasien dengan riwayat perawatan $\leq 14$ hari sebelum timbulnya gejala. Data diperoleh dari hasil pemeriksaan yang dilakukan pertama kali dalam rentang waktu 24 jam dari kedatangan pasien.

Pengambilan sampel dengan metode total sampling yang diambil meliputi keseluruhan unsur populasi. Instrumen penelitian menggunakan buku registrasi bangsal penyakit dalam dan data rekam medis pasien.

Data diolah secara manual yaitu data yang dibutuhkan dicatat dan dicari persentasenya kemudian ditampilkan dalam bentuk tabel distribusi frekuensi.

\section{HASIL}

Setelah dilakukan penelitian, maka didapatkan subjek penelitian sebanyak 365 pasien yang memenuhi kriteria inklusi.

Berdasarkan Tabel 1, didapatkan persentasi perempuan lebih banyak menderita Pneumonia Komunitas dibandingkan dengan laki-laki dengan nilai $54,25 \%$ dan $45,75 \%$. Pasien terbanyak adalah usia 60-69 tahun sebesar $43,56 \%$ dan terendah adalah usia $\geq 80$ tahun sebesar $20 \%$. Lama rawatan terbanyak adalah 1-5 hari sebesar $41,92 \%$, disusul $6-10$ hari sebesar 30,68\% dan terendah $>10$ hari sebesar 27,40\%. Dari 365 pasien didapatkan 42,74\% pasien meninggal dengan perbandingan perempuan lebih besar dibandingkan laki-laki yaitu $22,47 \%$ dan $20,27 \%$.
Tabel 1. Karakteristik penderita

\begin{tabular}{|c|c|c|}
\hline Variabel & $f(n=365)$ & $\%$ \\
\hline \multicolumn{3}{|l|}{ Jenis kelamin } \\
\hline Laki-laki & 167 & 45,75 \\
\hline Perempuan & 198 & 54,25 \\
\hline \multicolumn{3}{|l|}{ Usia (tahun) } \\
\hline $60-69$ & 159 & 43,56 \\
\hline $70-79$ & 133 & 36,44 \\
\hline$\geq 80$ & 73 & 20 \\
\hline \multicolumn{3}{|l|}{ Lama Rawatan (hari) } \\
\hline $1-5$ & 153 & 41,92 \\
\hline $6-10$ & 112 & 30,68 \\
\hline$>10$ & 100 & 27,40 \\
\hline \multicolumn{3}{|l|}{ Hidup/Meninggal } \\
\hline Hidup & 209 & 57,26 \\
\hline Laki-laki & 93 & 25,48 \\
\hline Perempuan & 116 & 31,78 \\
\hline Meninggal & 156 & 42,74 \\
\hline Laki-laki & 74 & 20,27 \\
\hline Perempuan & 82 & 22,47 \\
\hline
\end{tabular}

Berdasarkan Gambar 1 didapatkan Skor CURB-65 terbanyak pada pasien Pneumonia Komunitas adalah skor 2 yaitu $36,16 \%$, kemudian skor 3 dengan $26,30 \%$, skor 4 sebesar $16,44 \%$, skor 1 yaitu $15,34 \%$, skor $53,02 \%$, dan yang terendah adalah skor 0 yaitu $2,74 \%$.

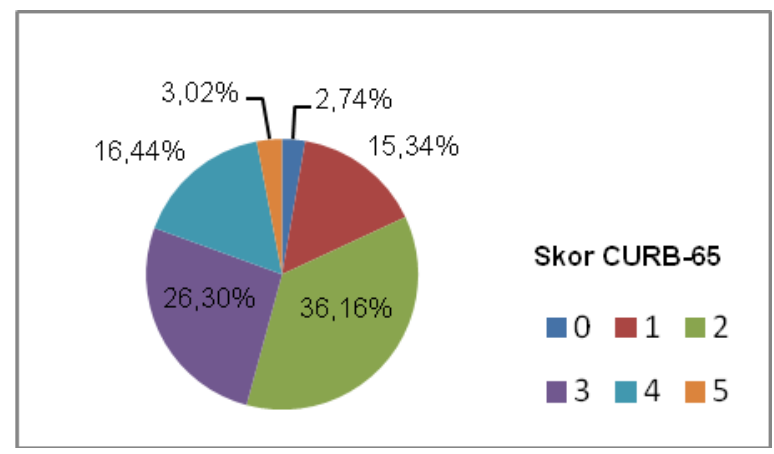

Gambar 1. Persentase pasien berdasarkan skor CURB-65

Berdasarkan Gambar 2 dibawah ini, didapatkan derajat keparahan Pneumonia Komunitas berdasarkan Skor CURB-65 tertinggi yaitu derajat berat $(45,75 \%)$, disusul derajat sedang $(36,17 \%)$, dan terendah yaitu derajat ringan $(18,08 \%)$. 


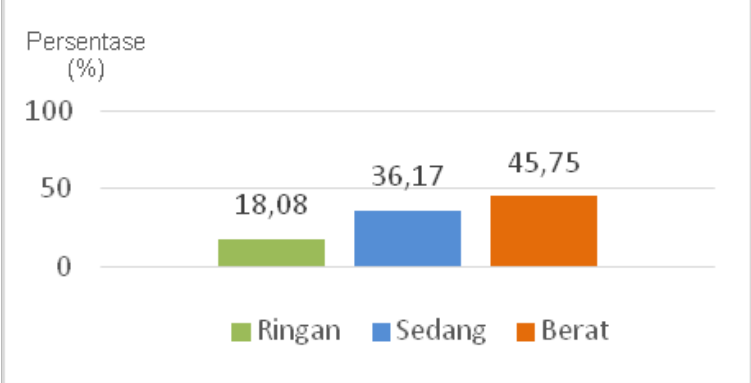

Gambar 2. Derajat keparahan pneumonia komunitas

\section{PEMBAHASAN}

Pada penelitian ini didapatkan bahwa lebih banyak pasien berjenis kelamin perempuan dengan Pneumonia Komunitas dibandingkan pasien laki-laki yaitu dengan perbandingan 198 (54,25\%) dan 167 $(45,75 \%)$. Hal ini sejalan dengan penelitian yang dilakukan oleh Nina Widasari pada tahun 2014 yang dilakukan di RSUP Dr. Kariadi Semarang. Dari 68 pasien Pneumonia Komunitas didapatkan 51,5\% pasien perempuan dan $48,5 \%$ pasien laki-laki. ${ }^{14} \mathrm{Hal}$ ini dapat disebabkan karena angka harapan hidup perempuan lebih besar dibandingkan dengan laki-laki yang dipengaruhi oleh gaya hidup dan faktor genetik.

Hasil penelitian ini berbeda dengan yang didapatkan oleh Rose Dinda Martini pada tahun 2013 yang dilakukan di RS Dr. M. Djamil dan RS Dr. Yos Sudarso Padang dengan jumlah pasien Pneumonia Komunitas 158 pasien, terdiri dari 51,9\% laki-laki dan $48,1 \%$ perempuan. Hal ini dikarenakan oleh penelitian tersebut mengambil data pasien dari poliklinik penyakit dalam, panti werdha, dan jemaat rumah ibadat. ${ }^{9}$ Sedangkan penelitian ini mengambil data pasien yang mendapat rawatan di bangsal penyakit dalam.

Pada penelitian ini, sebagian besar penderita Pneumonia Komunitas yang didapatkan adalah usia 60-69 tahun $(43,56 \%)$ dengan rerata usia 71,96 tahun. Kemudian disusul usia 70-79 tahun $(36,44)$ dan terendah usia $\geq 80$ tahun (20\%). Usia terendah yang didapatkan adalah 60 tahun dan usia tertinggi adalah 94 tahun. Hasil ini sejalan dengan penelitan yang dilakukan oleh Rose Dinda Martini yang mendapatkan usia rerata 71,84 tahun. Pasien Pneumonia Komunitas terbanyak didapatkan pada usia 60-69 tahun (43\%), diikuti usia $70-79$ tahun $(39,9 \%)$, dan $\geq 80$ tahun $(17,1 \%){ }^{9}$ Hal ini juga sejalan dengan penelitian yang dilakukan Nina Widasari dengan kejadian Pneumonia Komunitas terbanyak pada usia $>60$ tahun yaitu sebesar $69,6 \%$ dan pada penelitian I Gede Agus Sastrawan pada tahun 2014 yang dilakukan di RSUP Sanglah Denpasar dengan kejadian Pneumonia Komunitas dominan pada kelompok Geriatri (60-74 tahun) sebanyak $67,5 \% .^{14,15} \mathrm{Hal}$ ini sesuai dengan penelitian American Lung Association pada tahun 2015 yaitu salah satu kelompok berisiko tinggi untuk Pneumonia Komunitas adalah geriatri dengan usia 65 tahun atau lebih. ${ }^{5}$

Skor CURB-65 terbanyak ada pada pasien Pneumonia Komunitas pada penelitian ini adalah skor 2 (36,16\%), kemudian disusul oleh skor 3 (26,30\%). Penelitian ini sejalan dengan penelitian Nina Widasari yang mendapatkan skor terbanyak yaitu skor 2 $(57,4 \%)$ dan skor $3(23,5 \%)$ dan penelitian lain yang dilakukan oleh Eddy Surjanto et al di RS Dr. Moewardi Surakarta pada tahun 2013 juga mendapatkan skor terbanyak pada skor $2(39,3 \%)$ dan skor $3(19,0 \%){ }^{14,3}$ Hal ini disebabkan karena keterlambatan pasien datang untuk mendapatkan penatalaksanaan yang tepat dan keadaan awal saat pasien datang yang sudah menurun.

Pada penelitan Rose Dinda Martini didapatkan skor tertinggi pada skor $3(34,8 \%)$ dan disusul skor 2 $(33,5 \%) .{ }^{9}$ Penelitian yang dilakukan di RS Singapura pada tahun 2016 oleh Zoe Xiaozhu Zhang didapatkan skor tertinggi pada skor 1 (31,9\%) dan skor 2 (31,5\%) dan di India pada tahun 2010 oleh Bashir Ahmed Shah didapatkan skor tertinggi pada skor 2 (28\%) dan skor 1 $(20,7 \%) .^{16,17}$ Hal ini disebabkan karena data penelitian yang diambil adalah data pasien usia lanjut dan dipengaruhi oleh keadaan awal pasien saat datang ke rumah sakit yang berbeda-beda, sehingga menyebabkan perbedaan jumlah skor yang didapatkan.

Derajat keparahan Pneumonia Komunitas pada pasien yang terbanyak adalah derajat berat, kemudian disusul oleh derajat sedang, dan terendah pada derajat ringan dengan persentasi $45,75 \%, 36,17 \%$, dan $18,08 \%$. Hal ini sejalan dengan penelitian Rose Dinda Martini dengan hasil pasien yang terbanyak didapatkan pada derajat berat, kemudian derajat sedang dan terendah adalah derajat ringan dengan 
persentasi $63,3 \%, 33,5 \%$ dan 3,2\%. Pada penelitian Eddy Surjanto et al didapat hasil pasien terbanyak adalah derajat berat, disusul oleh derajat sedang, dan terendah derajat ringan dengan persentasi $41,7 \%$, $39,3 \%$ dan $19 \%$. $^{9,3} \mathrm{Hal}$ ini disebabkan karena keadaan awal saat pasien datang sudah menurun, keterlambatan pasien datang untuk mendapatkan penatalaksanaan yang cepat dan tepat dan penyakitpenyakit yang menyertai Pneumonia Komunitas.

Penelitian yang dilakukan oleh Nina Widasari didapatkan hasil derajat tertinggi pada derajat sedang, kemudian derajat berat, dan terendah derajat ringan yaitu $57,4 \%, 27,9 \%$, dan $14,7 \% .{ }^{14}$ Pada penelitian Zoe Xiaozhu Zhang et al didapatkan hasil derajat tertinggi pada derajat ringan $(49,93 \%)$, kemudian derajat sedang $(32,55 \%)$ dan terendah derajat berat $(17,52 \%) .^{16}$ Perbedaan ini dapat disebabkan selain karena data penelitian yang diambil adalah data pasien usia lanjut dan keadaan awal pasien saat datang ke rumah sakit, juga dapat terjadi karena perbedaan asal tempat rawatan dan penyakit yang menyertai Pneumonia Komunitas.

\section{SIMPULAN}

Derajat keparahan pneumonia komunitas pada geriatri didapatkan derajat berat 167 pasien (45,75\%), disusul derajat sedang 132 pasien $(36,17 \%)$, dan terendah yaitu derajat ringan 66 pasien $(18,08 \%)$.

\section{DAFTAR PUSTAKA}

1. Perhimpunan Dokter Paru Indonesia (PDPI). Pedoman diagnosis dan penatalaksanaan pneumonia komunitas di Indonesia. Jakarta: Badan Penerbit FKUI; 2014.hlm.3-24.

2. Dahlan Z. Buku ajar ilmu penyakit dalam. Edisi ke6. Jakarta: Pusat Penerbitan IImu Penyakit Dalam FKUl; 2009.hlm.1608-19.

3. Surjanto E, Yusup SS, Reviono, Harsini, Dwi I. Perbandingan tiga metode prediksi secara restrospektif dalam menilai derajat pneumonia komunitas pada pasien lanjut usia di Rumah Sakit Dr. Moewardi Surakarta. Jurnal Respirologi Indonesia. 2013;33(1):34-9.

4. Andayani N. Tingkat mortalitas dan prognosis pasien pneumonia komunitas dengan sistem skoring CURB-65 di ruang rawat inap paru RSUD Dr. Zainoel Abidin Banda Aceh. Jurnal Kedokteran Syiah Kuala. 2014;14(1):14-9.

5. American Lung Association. Pneumonia (diunduh 25 Mei 2016). Tersedia dari: http://www.lung.org/ lung-health-and-diseases/lung-disease-lookup/ pneumonia/learn-about-pneumonia.html.

6. Kementrian Kesehatan Republik Indonesia. Riset kesehatan dasar 2013. Jakarta: Kementrian Kesehatan RI; 2013.

7. Pilotto A, Addante F, Ferrucci L, Leandro G, D'Onofrio G, Corritore $M$, et al. The multidimensional prognostic index predicts shortand long-term mortality in hospitalized geriatric patients with pneumonia. J Gerontol A Biol Sci Med Sci. 2009;64A(8):880-7.

8. Dinas Kesehatan Kota Padang. Laporan tahunan tahun 2013 edisi 2014. Padang: Dinas Kesehatan Kota Padang; 2014.

9. Martini RD. Prealbumin dan CURB-65 sebagai faktor prediktor kematian pada pasien usia lanjut dengan pneumonia komunitas (tesis). Jakarta: Fakultas Kedokteran Universitas Indonesia; 2013.

10. File TM Jr, Marrie TJ. Burden of communityacquired pneumonia in North American adults. Postgrad Med. 2010;122(2):130-41.

11. Armitage K, Woodhead M, Lippincott W, Wilkins. New guidelines for the management of adult community-acquired pneumonia. Curr Opin Infect Dis. 2007;20(2):170-6.

12. Mandell LA, Wunderink RG, Anzueto A, Bartlett JG, Campbell GD, Dean NC, et al. Infectious diseases society of America/American Thoracic Society consensus guidelines on the management of community-acquired pneumonia in adults. CID. 2007;44(2):S27-S72.

13. Lim WS, Van der Eerden MM, Laing R, Boersma WG, Karalus N, Town GI, et al. Defining community acquired pneumonia severity on presentation to hospital: an international derivation and validation study. Thorax. 2003;58(5):377-82.

14. Widasari N. Pola derajat keparahan pneumonia dan terapi antibiotik empirik pada pasien community-acquired pneumonia (CAP) yang dirawat di RSUP Dr. Kariadi Semarang (skripsi). 
Semarang: Fakultas Kedokteran Universitas

Diponegoro; 2014.

15. Sastrawan IGA. Peranan kadar leptin sebagai biomarker status nutrisi berkorelasi negatif dengan derajat pneumonia komuniti pada pasien geriatrik (tesis). Denpasar: Fakultas Kedoteran Universitas Udayana; 2014.

16. Zhang ZX, Zhang Weidong, Liu Ping, Yang Yong, Tan WC, Ng HS, Fong KY. Prognostic value of pneumonia severity index, CURB-65, CRB-65, and procalcitonin in community-acquired pneumonia in Singapore. Journal. Proceedings of Singapore Healthcare. 2016;25(3):139-47.

17. Shah BA, Ahmed Wasim, Dhobi GN, Shah NN, Khursheed SQ and Haq I. Validity of Pneumonia Severity Index and CURB-65 Severity Scoring Systems in Community Acquired Pneumonia in an Indian Setting.Indian J Chest Dis Allied Sci. 2010;52(1):9-17. 